\title{
Influence of Job Stress on Job Satisfaction: Empirical Evidence from Ghana Police Service
}

\author{
Gerald Dapaah Gyamfi ${ }^{1}$ \\ ${ }^{1}$ Department of Business Administration, University of Professional Studies, Accra, Ghana \\ Correspondence: Gerald Dapaah Gyamfi, Department of Business Administration, University of Professional \\ Studies, P. O. Box LG 149, Legon, Accra, Ghana. Tel: 233-242-874-208. E-mail: gdgyamfi@gmail.com
}

Received: June 3, 2014

Accepted: August 8, 2014

Online Published: August 25, 2014

doi:10.5539/ibr.v7n9p108

URL: http://dx.doi.org/10.5539/ibr.v7n9p108

\begin{abstract}
The purpose of this research was to identify and explore the influence of job stress on job satisfaction among police officers using empirical evidence from Ghana Police Service. The exploratory study was carried out at Accra North Division of Ghana Police Service in 2011. A prospective analysis was completed on 200 Police officers who were selected, using convenience sampling, from a population of 335 personnel at the Division. The researcher carried out analysis into the influence of physical environment, role ambiguity, role overload (moderators of stress), supervisor support and coworker support (social support) on job satisfaction among the officers. Regression analysis revealed the following findings. First, role ambiguity and physical environment had negative and non-significant relationship with job satisfaction. Second, coworker support had moderately positive significant influence with job satisfaction. Third, there was a positive non-significant relationship between supervisor support and job satisfaction. Fourth, there was a positive significant relationship between coworker support and job satisfaction. The author recommends that leadership of Police administration should pay much attention to the psychological and physiological needs of their police officers to improve upon the job satisfaction among the officers.
\end{abstract}

Keywords: Ghana, influence, job, policing, satisfaction, stress

\section{Introduction}

The nature of policing in peace keeping of a nation enables the operations of police officers highly demanding and essential for the development of any nation. In some parts of the world issues that affect job satisfaction of police officers include "repeatedly dealing with death, serious injury, horrific crime scenes, the need to be constantly alert whether on or off duty, and being ostracized by communities, friends, and family" (Smith \& Charles, 2010, p. 320). Among the professions that the workers undergo serious stress is that of policing (Chapman, 2009). The manner of managing, coping, and psychological adjustment of stress of workers has influence on their job satisfaction (Sunderam \& Kumaran, 2012). Studies have indicated that job satisfaction is affected by different aspects of job stressors that have either direct or indirect influence (Spector, 1997; Fisher, 1992). It has been established that occupational stress is a major factor that has impact on the performance of public institutions, including the police service (Fisher, 1992).

\subsection{Overview of Ghana Police Service}

Historians trace policing in Ghana beyond the era of the colonial administration of Ghana (Gyamfi, 2012). For instance, the Ashanti Empire had their own system of policing known as Akwansrafo who used to patrol to ensure that the people obeyed the laws that protected the jurisdiction of the Ashanti kingdom (Tankebe, 2008). However, it was in 1897 that the Gold Coast Police Ordinance was promulgated to constitute the Gold Coast Constabulary with 400 men. The regime translated the Gold Coast Constabulary to Ghana Police Force by Police Service Act 350(1) in 1970 (Gyamfi, 2012).

Stress and its related job satisfaction in Ghana has been a major issue of concern to the government and the people of Ghana since the establishment of Ghana Police Force. The interventions by the various governments of Ghana to address most of the major concerns that affect the stressful life and performance of Ghana Police Service (metamorphosed from Ghana Police Force) have not yielded much dividend to the officers of the service. 


\subsubsection{Ghana Police Reports on Stress Related Issues}

Aning (2006) indicated that in 1951 the government of Ghana received a report from a committee, commonly known as Young's Report, on looking into resourcing the police force and training the personnel for proper policing. Boyes Report on how to provide a befitting structure that will alleviate the stressful conditions of Ghana Police Service (GPS) and modernize the service was received for action by the government in 1971. In 1986, another report known as Tibiru Report on selection and promotion of the personnel and how to address the problem of dishonesty in the selection of personnel that was having serious implication on job satisfaction among the officers was received. There was the Archer Report in 1997 on assessing the manpower and logistical needs (factors affecting stress) of the service for effective policing was sent to the government for action. Okludzeto Committee was also commissioned to look into a police action that led to the death of 126 spectators at a football match between Accra Hearts of Oak and Kumasi Asante Kotoko (Football teams in Ghana) match on the $9^{\text {th }}$ May, 2001 was also received. All these commissions were tasked to look into effective ways of reducing the stressful conditions of the police service and thereby to find better ways of improving the job satisfaction among police officers.

\subsubsection{Ghana Police Service Stressful Conditions}

In Ghana, it has been reported that stressful conditions that affect the job satisfaction of the police officers include poor accommodation. According to the performance audit of GPS (Ghana Auditor-General's Report on Ghana Police Service, 1998), the poor accommodation of the officers put undue pressure on the personnel and put them under severe stressful conditions. This stressful condition of the police officers affected their job satisfaction. The Annual Report (Accra North Divisional Orderly Room Annual Report, 2010) had in it that as a result of stressful conditions most police officers intermittently fell sick. For instance the report indicated that during 2010, 63 personnel were granted excuse duties for 220 days due to sickness.

According to GPS Report (Police Headquarters Establishment Unit Report, 2011), between January, 25th, and February 26th, two police officers at GPS committed suicide. The Daily Graphic Newspaper in 2012 reported that a police officer was shot dead during a fire exchange between some suspected armed robbers and the police. Research has shown that even though police officers are trained, supported, and sometimes are provided with counseling and debriefing, these factors do not have much effect on their job satisfaction. Among the factors that have negative effect on job satisfaction among the police officers is poor means of addressing post-traumatic stress disorder that "keeps them in an ongoing cycle of re-traumatization" (Rees \& Smith, 2008, p. 267).

\subsection{Research Purpose}

The main purpose of this research is to examine the variables; job stress and social support that may be influential in predicting job satisfaction among the GPS officers. This research is to contribute more theories in the area of job stress and its associated job satisfaction. The study seeks to examine how job stress relates with job satisfaction among police officers. The study also draws attention of leadership of police services to focus on dealing with issues relating to job stress and policing and the various interventions that should be needed to enhance police job satisfaction. Even though the research is limited to policing in Ghana, the findings may provide some transferable knowledge to policing in other parts of the world, especially to policing in Africa. The study is useful because of how police stress is more pronounced among the officers, especially the younger and more educated officers, where the expectation of performance is very high (Sundaram \& Kumaran, 2012).

Many Ghanaians have the perception that there is a problem with the performance of the officers of GPS that has tremendous influence on their job satisfaction (Avuyi, 1995; Osabutey, 2009). There is also the perception of lack of systematic efforts established that seriously handles job stress among the personnel of GPS (Aning, 2006). Even though there are so many reports on GPS to address most of the problems associated with the stressful conditions and improve the job satisfaction among the personnel, not much action has been considered to address the issues raised in the reports (Aning, 2006). The current research will give indication of the necessity to improve the organizational climate affecting police officers (Selokar, Nimbarte, Ahana, Gaidhane, \& Wagh, 2011) with the view of enhancing their job satisfaction.

In Ghana, policing and the stress associated with the role of the officers have not received much attention in the literature and seems neglected (Boakye, 2005). This neglect has created a lack of literature and a knowledge gap in research into policing and job satisfaction in Ghana. The findings, resulting from this study, will therefore serve as a source of knowledge for future researchers on the relevance of effective stress management and what goes to ensure a healthy policing resulting from job satisfaction of the officers. The findings will also be useful for the study of the relationship between stress that the officers undergo and the satisfaction derived from policing at other parts of the world. 


\section{Literature Review}

\subsection{Job Satisfaction}

The pleasurable emotional state of a worker that results from the appraisal of that worker's job experience is what is referred to as job satisfaction (Locke, 1976). A research carried out to investigate the influence of job stress on job satisfaction among public institution that have role stress, including role ambiguity, role conflict, and role overload, proved to have negative relationship (Ussahawanichakit, 2008). Police literature reveals that there is a decline in the retention rate of police patrol officers due to poor job satisfaction (Julseth, Ruiz, \& Hummer, 2011). A longitudinal study of policing indicates that recruits enter police departments with high motivation and commitment but the motivated and commited attitudes decline swiftly over time as a result of poor job satisfaction (Maanen, 1975).

\subsection{Job Stress}

In the police service, stress associated with traumatic situations, for example, after homicide investigations can be a worrying situation. For instance the stress and confusing states that police officers go through when there is death notification that police patrol and the homicide investigation teams are to investigate are worrying (Miller, 2006). When even the dead body is found, the mental stress and agony that they go through during body identification affect their cognitive behavior. Sometimes they deal with the mentally ill, because of substance (e.g. narcotics) abuse and facing hostile armed people (Miller, 2006).

In the course of the daily operations of the officers they go through some hustles that cognitively affect their mental and physical emotions as they ponder on their own safety and that of their family because of the nature of their work. They get traumatized when their superiors deploy them to challenge certain catastrophic events such as war outbreak, automobile accidents, and violent physical attacks (Robbins \& Judge, 2007). Police stress may also come from the daily activities engaged at work, poor inter-personal relationships, and everyday living circumstances. Internal working climate of policing, such as shift schedules that disrupt sleep patterns; lack of promotion, sleepless nights because of call to duty, and lack of autonomy are sources of stress related to policing (Cooper, Davidson, \& Robbinson, 1982).

\subsection{Policing and Stressful Conditions}

Studies have shown that police officers have more work-related stress than workers in most other professions. This stressful condition results from the nature of the work of the officers that expose them to certain hazardous circumstances that result in burnout and premature retirement among many of the officers (Anshel, 2000). In addition to experiencing job-related stress by police officers, the officers usually confront certain deviant situations that make them susceptible to the exposure of very high risk. Prominent among the awkward dangerous work-life situations associated with policing include dealing with unlawful and dangerous actions by citizens and lack of general social support that expose them to wanton risk. These exposures compel some of police officers to indulge in certain practices that are manifestations of stress such as high consumption of alcoholic beverages, suicide, and marital divorce (Storch \& Panzarella, 1996).

Policing is one of the most stressful occupations because the personnel are exposed, on daily basis, to stressful and traumatic events (Sijaric-Voloder \& Capin, 2008). These events result from the nature of police service, in maintaining peace and order that expose the personnel to many stressful conditions. For instance, the "officers confront the undesirable of our society on a daily basis... they often see the worst of what mankind has to offer. Most of the personnel suffer injuries, death, and lose comrades who die during police operation" (Bandzeviciene, Birbilaite, \& Dirzyte, 2010, p. 21). Police officers get exposed to traumatic and elevated risk. Policing has therefore been classified among the most stressful jobs in the Western society (Miller, 2006). The impact of stress among police officers can be decreased through enhancement of awareness of the risk involved and boosting the self-esteem of the personnel. Taking the officers through the stressful conditions and the strategies that will boost their morale in the course of their work will contribute to alleviate their stressful conditions. This approach will dissuade them from entertaining any fear associated with the duty (Swanson \& Territo, 1983).

\subsection{Relationship between Job Satisfaction and Job Stress}

The type of stress that influences job satisfaction experienced by police officers mostly come from satisfaction of both psychological and physiological needs. Researchers into policing have not done much study on the relationship between job stress and job satisfaction among the police officers in Africa (Osabutey, 2009) even though some systematic studies on occupational stress and job satisfaction have been carried out in other areas by some researchers in other fields (Bandzeviciene, Birbilaite, \& Dirrzyte, 2010). Some studies on the relationship between job stress and job satisfaction have revealed that job stress and job satisfaction correlate 
negatively in some aspects of jobs (Wu, 2011; Mahendran \& Deyanesan, 2013). According to Elis (2006), acute stress affects the mental models and trans-active memory that has tremendous effect on job satisfaction. This explains why under acute stress work teams perform poorly. For instance, studies on police officers in China found that job stress and job satisfaction have significant negative relationships (Wu, 2011).

\subsection{Job Stressors}

Preliminary discussions with most police officers at GPS revealed role overload, role ambiguity, physical environment, co-worker support, and supervisor support are stressors that the police officers are mostly concerned about. The focus of this study of job stressors among police officers was therefore on role overload, role ambiguity, physical environment, co-worker support, and supervisor support. This is also based on how so many researchers on job stress consider these stressors in their studies (Beehr, Jex, Stacy, \& Murray, 2000). Moreover, most of the causes of stress among practitioners of public institutions come from the roles they play at work (Bunnell, 2004).

A research carried out by Mensoor, Fida, Nasir, and Ahmad (2011) proved that job stress measured by role overload, physical environment, and role ambiguity negatively influenced job satisfaction of the employees. There is role overload when workers have the view that their jobs demand a lot from them that they work more than what their ability and time can permit them to do (Schultz \& Schultz, 2006). A research by Jamal (1985) on the relationship between job stress and job satisfaction indicates that high role overload leads to lower level of job satisfaction. Empirical evidence from a research carried out by Nele and Hans (2006) also indicates that too much work, in terms of quality and quantity, has negative influence on job satisfaction. Fatigue and workload are some of the policing stress factors that increase the turnover rates among the officers (Julseth, Ruiz, \& Hummer, 2011).

There is role ambiguity when there is uncertainty, or an individual has information that is inadequate, about the individual's role performed at work. Role ambiguity is experienced in most cases when an individual is tasked to do complex task or the expectation of performance on the job is not made clear to the individual (Nele \& Hans, 2006). In policing, the organizational and experiential stressors emanating from role ambiguities have serious negative repercussions on the satisfaction and performance of the officers (Menard \& Arter, 2013).

Physical environment refers to the physical working conditions of a worker that relate to stress. The stressful conditions include poor illumination, pollution, high temperatures, noise, and shift work (Schultz \& Schultz, 2006). Workers with poor fit with their physical working environment suffer job stress resulting from damages caused by both physiological and psychological means (Caplan, Cobb, \& French, 1975). Some studies have revealed that poor physical working conditions have negative influence on job satisfaction (Kim et al., 2002). These stressors related to the police organizational climate have significant negative influence on the job satisfaction of the personnel (Pagon, Spector, Cooper, \& Lobnikar, 2011).

This researcher now hypothesizes, after given consideration to the aforementioned studies on the job stressors, as follows:

$\mathrm{H}_{1}$ : Role overload is negatively related to job satisfaction among the GPS officers.

$\mathrm{H}_{2}$ : Role ambiguity is negatively related to job satisfaction among the GPS officers.

$\mathrm{H}_{3}$ : Physical environment is negatively related to job satisfaction among GPS officers.

\subsection{Social Support}

At work, social support that affects job satisfaction of police officers comes from all the individuals who work with an officer and it includes support from the Police Administration, supervisor support, support from coworkers and support from subordinates (Mitchel, Kotrba, Mitchelson, Clark, \& Baites, 2011). This researcher concentrates on two sources of social support; coworker support and supervisor support because most researchers have concentrated on these two sources to reduce the effect of job stress on workers (Beehr, 1985).

Studies on policing concerning the relationship between social support received by the officers and job satisfaction indicated that the personnel who were not satisfied showed limited supervisor support (Kawada \& Otsuka, 2011). A related study on job stress, associated with coworker support and job satisfaction also revealed that "high level of stress experienced in the job is positively, strongly, and significantly associated with the dependent variables" (Gul \& Delice, 2011, p. 19). Research has shown that police officers who are females, for example, suffer more stressful conditions than their male counterparts and also junior police officers experience more stress level than the senior police officers (Omolayo, 2012). The use of critical incident peer support programs encourages the personnel who are to embark on a hostile action enable the officers to work with 
confidence, vim, and vigor. This intervention is useful for reducing the stress level of the officers.

Social support strategies involving the use of family members of the officers also can be a helpful intervention to bring about job satisfaction among the officers who embark on service operations or exercises. For instance the use of family members, especially the spouses, encourages the officers who embark upon hostile actions (Miller, 2006).

After considering the studies on social support and the outcomes, this researcher now proposes the following hypotheses:

$\mathrm{H}_{4}$ : Supervisor support is positively related to job satisfaction among GPS officers.

$\mathrm{H}_{5}$ : Coworker support is positively related job satisfaction among GPS officers.

\section{Methodology}

In this research, the author used a cross-sectional field survey design to solicit the views of the respondents on the influence of job stress on job satisfaction among police officers at GPS. The instrument used for the study was adopted from Karasek (1985). In using the adopted instrument to measure the work stress level and job satisfaction among the personnel of GPS, the researcher based the study on conceptual framework of abbreviated version of Karasek's Job Content Questionnaire (JCQ) (Karasek, 1985). Many researchers have used and tested JCQ in many cultural settings around the globe with high validity, especially in the United States, United Kingdom, Netherlands, and Japan. Nevertheless, Karasek's model was based on different samples from different occupations and "therefore the results may have been confounded by socioeconomic status" (Sheffield, Dobbie, \& Carroll, 1994, p. 33).

\subsection{Data Collection}

This study used convenience sampling technique to collect the data. This technique of data collection was appropriate because policing involves more movements in and out of stations. This technique involves the use of the available subjects to serve as participants (Marczuk, DeMatteo, Festinger, 2015).

\subsection{Population and Sample}

The population of interest was 335 police officers of the GPS, Accra North Division. The study sampled 200 out of the population serving under Accra North Division of GPS in 2011. These included 20\% senior officers and 80\% junior officers, $67.3 \%$ male and $32.7 \%$ female full-time officers of the Service who were between 18 and 60 years old. The respondents duly completed and returned 150 of the administered questionnaires (response rate of $75 \%$ ).

\subsection{Measure}

\subsubsection{Dependent Variables}

In this study the dependent variables are job satisfaction and demographics. Two survey items were used to measure job satisfaction, "You are satisfied with the police job you do" and "Your work position is well fit to your needs" (Chronbach's alpha was .84). The demographic items were age, gender, rank in service, and tenure. The job satisfaction items were developed by Karasek (1985) and they were measured using a 4-point Likert scale ranging from 1 (strongly disagree) to 4 (strongly agree).

\subsubsection{Independent Variables}

The researcher used two main groups of independent variables: job stress and social support. All the items used to measure the independent variables were adopted from Karasek (1985) and they were considered from a continuum of 4-point Likert scale, ranging from 1(strongly disagree to 4(strongly agree). Three items were used to measure job stress (role overload, role ambiguity, and physical environment). The average of two items for the role overload used include, "Your job requires that you learn new things," and "Your job requires a high level of skills" (Cronbach's alpha was .87). In measuring role ambiguity the researcher used the average of three items: "Your job demands that you do things over and over again," "Your work schedule was changing repeatedly," and "You are always scared that you may lose your job" (Cronbach's alpha, .73). One item was used to measure physical environment, "Your work does not allow you freedom to decide how to do your job" (Cronbach's alpha, .69).

In measuring social support, the researcher used the average of two items. These items were supervisor support and co-worker support. For supervisor support; "Your supervisor is not helpful in getting the job done," and "You are exposed to hostility or conflict from the people you work with" (Cronbach's alpha, .76). For co-worker support, "The people you work with are not helpful in getting the job done," and "Your co-workers are not helpful in getting the work done" (Cronbach's alpha, .77). 


\subsubsection{Statistical Test}

The researcher used standard multiple regression analysis to test the effect of job stress on job satisfaction and the effect of social support on job satisfaction of employees of GPS. The researcher again used regression analysis because the sample size was sufficient, making regression more powerful way to test the relationship between the variables than other statistical methods such as the use of non-parametric tests (Vogt, 2007). Cohen and Will (1985), recommend that regression analysis should be the best approach in situations in which the predictor variables are continuous.

\section{Empirical Results}

\subsection{Demographic Characteristics of Respondents}

As indicated in Table 1, in the study 150 police officers participated. The results show that $101(67.3 \%)$ of the participants were men (mean, 25.818; standard deviation, .667). Six (4\%) of the participants were fewer than 20 years, $86(57.3 \%)$ age ranged from 20 to 34 years. The participants whose age ranged from 35 to 49 years were $49(32.7 \%)$, and those who were above 50 years were nine $(6.0 \%)$. The mean age was 2.4067 and standard deviation, .667 .

On tenure of office, $103(68.7 \%)$ of the participants had worked continuously with GPS less than 6 years. The number that had served between six and 10 years were $26(17.3 \%)$, those served from 11 to 15 years were 11 $(7.3 \%)$, and those served 16 years or more were $10(6.7 \%)$. The mean tenure of office was 3.289 with standard deviation of .895 . One hundred and twenty $(80.0 \%)$ of the participants were classified as junior rank officers and $30(20.0 \%)$ of them as senior officers. The mean was 1.520 (standard deviation, .895).

Table 1. Demographic characteristics of respondents $(\mathrm{N}=150)$

\begin{tabular}{ccccc}
\hline & & $\mathrm{N}(\%)$ & Mean & Standard Deviation \\
\hline Gender & Female & $101(67.3)$ & 25.818 & .667 \\
Age & $49(32.7)$ & & .667 \\
& Less than 20 years & $6(4.0)$ & 2.4067 & \\
20-34 years & $86(57.3)$ & & .895 \\
35-49 years & $49(32.7)$ & & \\
Tenure of Service & 50 years and above & $9(6.0)$ & & \\
& Less than 6 years & $103(68.7)$ & & \\
& 6-10 years & $26(17.3)$ & & \\
& $11-15$ years & $11(7.3)$ & & \\
& 16 years and above & $10(6.7$ & & \\
Rank in Service & Junior Rank & $120(80.0)$ & & \\
& Senior Rank & $30(20.0)$ & & \\
\hline
\end{tabular}

The results as shown in Table 2, indicate that a negative but non-significant relationship exists between role ambiguity and job satisfaction $\left(\mathrm{r}=-0.82, \mathrm{p}=\mathrm{n} . \mathrm{s}\right.$.), $\mathrm{H}_{2}$, not confirmed. The relationship between physical environment and job satisfaction was non-significant and negative $(r=-.110, p=n$. s. $), H_{3}$, not confirmed. The findings also showed that a negative but moderately significant relationship exists between role overload $(\mathrm{r}=$ $-.162, \mathrm{p}<.05)$ and job satisfaction among the GPS officers, $\mathrm{H}_{1}$, confirmed. The findings further revealed that positive but non-significant relationship exists between supervisors' support $(\mathrm{r}=.043, \mathrm{p}=\mathrm{n}$. $\mathrm{s}$.) and job satisfaction, $\mathrm{H}_{4}$, not confirmed. However, there was a positive and moderately significant relationship found among coworkers' support $(\mathrm{r}=.234, \mathrm{p}<.05)$ and the job satisfaction of the GPS officers, $\mathrm{H}_{5}$ confirmed, in line with the findings of Cohen (1988).

There were significant mean differences among the independent variables (role overload, role ambiguity, physical environment, coworker support, and supervisor support) and job satisfaction $[\mathrm{F}(5,144)=3.22, \mathrm{p}<.05]$. 
Table 2. Descriptive statistics, reliability and correlation for all continuous variables of the study $(\mathrm{N}=150)$

\begin{tabular}{|c|c|c|c|c|c|c|}
\hline & JS & RO & SS & $\mathbf{R A}$ & PE & CS \\
\hline Job Satisfaction (JS) & - & - & - & - & - & - \\
\hline Role Overload (RO) & $-.162 *$ & - & - & - & - & - \\
\hline Supervisor's Support (SS) & .043 & $-.130^{*}$ & - & - & - & - \\
\hline Role Ambiguity (RO) & -.082 & .056 & -.142 & - & - & - \\
\hline Physical Environment (PE) & -.110 & -.032 & $.073^{*}$ & .059 & - & - \\
\hline Coworkers Support (CS) & $.234 *$ & -.164 & $.176^{*}$ & $.137^{*}$ & -.122 & 1 \\
\hline Mean & 3.033 & 3.183 & 3.175 & 2.873 & 3.112 & 3.168 \\
\hline Standard Deviation & .631 & .441 & .372 & .500 & .346 & .402 \\
\hline Chronbach's Alpha & .84 & .87 & .76 & .73 & .69 & .77 \\
\hline
\end{tabular}

* Correlation is moderately significant at the 0.05 (2-tailed).

\section{Discussion and Conclusion}

This study was carried out to explore the influence of job stress on job satisfaction in policing using GPS for the empirical study after identifying a gap in the literature on empirical research in this area. The researcher focused on the following job stressors: role overload, physical environment and role ambiguity.

\subsection{Discussion}

After reviewing literature on these stressors, the researcher propounded three hypotheses: $\mathrm{H}_{1}$ "Role overload is negatively associated with job satisfaction," $\mathrm{H}_{2}$, "Role ambiguity is negatively associated with job satisfaction," and $\mathrm{H}_{3}$ "Physical environment is negatively associated with job satisfaction." The researcher also considered stress emanating from social support and its influence on job satisfaction. Based on literature reviewed the researcher further propounded the following two hypotheses as: $\mathrm{H}_{4}$ "Supervisor support is positively associated with job satisfaction," and $\mathrm{H}_{5}$ "Coworker support is positively associated with job satisfaction." Multiple regression analyses carried out on the relationship between job stress and job satisfaction confirmed $\mathrm{H}_{1}$ and $\mathrm{H}_{5}$ but the strength of the relationships is moderate. The confirmation of $\mathrm{H}_{1}$ supports the findings from Nele and Hans (2006), Jamal (1985), and that of Julseth, Ruiz, and Hummer (2011). The result indicating positive influence of coworker support on job satisfaction $\left(\mathrm{H}_{1}\right)$ supports the findings of Beehr (1986), and Gul and Delice (2011). Even though the relationships between the influence of role ambiguity, physical environment, supervisor support on job satisfaction is non-significant, these items also play a role in influencing job satisfaction, therefore the focus of the Police Administration is also expected to be drawn to these items in reducing stress.

The outcome of this study proves that at least role overload and coworker support should be considered as avenues to enhance job satisfaction among the police officers. It is, therefore, recommended that more attention to reduce the stressful conditions of the officers towards improving job satisfaction among the officers should be focused on the roles assigned to the officers and the support that the workers receive from other officers. This researcher is of the view that the Police Administration should create a working condition that will foster closer ties among the officers as coworkers.

\subsection{Recommendations}

Based on the findings of the research there is a recommendation that to improve job satisfaction in policing it is necessary to institute stress management programs to help address the stressful conditions that the personnel go through when executing their duties, especially focusing on the job roles assigned to the officers. In policing, it is very important to pay attention to the psychological and physical needs of the officers to improve their job satisfaction when assigning job roles to them.

Other interventions that police authorities may consider to reduce the stress and improve job satisfaction among the personnel include the improvement in social support systems among the personnel. There must be improvement in the relationship between the superiors and their subordinates. The authorities must also consider improving coworker relationships by instituting some programs that enhance the relationships. The police institution must also put in place cultural practices that will make the officers become keepers of one another. These strategies will improve job satisfaction among the personnel. 
Police administration can mitigate the stress level and improve the satisfaction of the officers by using interventions that highlight critical success factors and best practices that can develop a general framework for the development of the officers. The interventions should enhance the skills of the officers in combatting crime and other offences. Interventions that can be used as strategies to improve job satisfaction of the officers include the creation of working environment that is friendly and provision of improved facilities to enhance the abilities of the officers to perform their duties (Gul \& Delice, 2011).

This study was carried out not without limitations. The following limitations and recommendations will guide future researchers in their quest to carry out research in the area of stress or job satisfaction. In this study the researcher considered only three aspects of job stressors; role overload, role ambiguity, and physical environment. It is recommended that future researchers should focus on identifying other stressors that reflect the stressful life of police officers. Only two aspects of social support related to stress; coworker support and supervisor support were considered by this researcher. The sources of the social support factors were all internal. Future researchers can also consider external stress factors, such as family life, that affect the job satisfaction of police officers (Miller, 2006). Finally, this correlational study does not develop inferences based on causality. It is, therefore, recommended that future researchers into this area focus on longitudinal studies (Korunka, Scharitzer, Carayon, \& Sanfort, 2003).

\section{References}

Aning, E. K. (2006, April). An overview of the Ghana Police Service. Journal of Security Sector Management, $4(2), 1-37$.

Anshel, M. H. (2000). A conceptual model and implications for coping with stressful events in police work. Crime Justice and Behavior, 27(3), 375-400. http://dx.doi.org/10.1177/0093854800027003006

Arter, M. L. (2008, January). Stress and deviance in policing. Deviant Behavior, 29(1), 43-69. http://dx.doi.org/10.1080/01639620701457774

Avuyi, P. (1995). Ghana police service is sick. Chronicle, August 10.

Bandzeviciene, R., Birilaite, S., \& Dirzyte, A. (2010). Stress, coping and coherence in criminal police officers. Socialiniu Mokslu Studijos, 4(8), 21-37.

Beehr, T. A. (1985). The role of social support in coping with organizational stress. In T. A. Beehr, \& R. S. Bhaget (Eds.), Human stress and cognition in organization (pp. 375-398). New York, NY: John Wiley \& Sons.

Beehr, T. A., Jex, S. M., Stacy, B. A., \& Murray, M. A. (2000). Work stressors and coworker support as predictors of individual strain and job performance. Journal of Organizational Behavior, 21, 391-405. http://dx.doi.org/10.1002/(SICI)1099-1379(200006)21:4<391::AID-JOB15>3.0.CO;2-9

Boakye, K. A. (2005, September). The concept of capable guardianship: Exploring police views on tourist protection in Ghana. Journal of Criminal Justice, 33(5), 413-427.

Bunnell, T. (2004, April). Overload and role ambiguity in international schools: The evidence from public relations activities. International Schools Journal, 23(2), 22-27.

Caplan, R. D., Cobb, S., \& French, J. R. P. (1975). Job demands and worker health: Main effects and occupational differences. Washington, DC: U. S. Department of Health Education and Welfare.

Chapman, D. (2009, Winter). Emotional labor in the context of policing in Victoria: A preliminary analysis. International Journal of Police Science \& Management, 11(4), 476-492. http://dx.doi.org/10.1350/ijps.2009.11.4.145

Cohen, J. W. (1988). Statistical power analysis for the behavioral sciences (2nd ed.). Hillsdale, NJ: Lawrence Erlbaum Associates.

Cohen, S., \& Wills, T. A. (1985). Stress, social support, and the buffering hypothesis. Psychological Bulletin, 98(2), 310-357. http://dx.doi.org/10.1037/0033-2909.98.2.310

Cooper, C. L., Davidson, M. J., \& Robinson, P. (1982). Stress in police service. Journal of Occupational Medicine, 24, 30-36.

Elis, A. P. J. (2006, June). System breakdown: The role of mental models and trans-active memory in the relationship between acute stress and team performance. Academy of Management Journal, 49(3), 576-589. http://dx.doi.org/10.5465/AMJ.2006.21794674 
Fisher, A. B. (1992). Welcome to the age of overwork. Fortune, 64-67, 70-71.

Gul, Z., \& Delice, M. (2011). Police job stress and stress reduction/coping programs: The effect on the relationship with spouses. Turkish Journal of Police Studies, 13(3), 19-38.

Gyamfi, G. D. (2012). Evaluation of motivating incentives on performance of police personnel at Tema Community 2. In D. Palmer, M. M. Berlin, \& D. K. Das (Eds.), Global Environment of Policing. New York: CRC (Taylor \& Francis Group).

Jaccard, J., Turrisi, R., \& Wan, C. K. (1990). Interaction effects in multiple regression. Newbury Park, CA: Sage.

Jamal, M. (1985). Job stress and job performance controversy: An empirical assessment. Organizational Behavior and Human Performance, 33(1), 1-21. http://dx.doi.org/10.1016/0030-5073(84)90009-6

Jex, S. M. (1998). Stress and job performance: Theory, research, and implications for managerial practices. Thousand Oaks, CA: Sage Publishers.

Johnson, R. (2013, Spring). Bio-psycho-sociocultural operation enduring/operation Iraqi freedom women veterans as civilian police officers: Mild traumatic brain injury and post-traumatic stress disorder challenges. International Journal of Police Service and Management Science, 15(1), 45-50.

Julseth, J., Ruiz, J., \& Hummer, D. (2011, Autumn). Municipal police officer job satisfaction in Pennsylvania: A study of organizational development in small police departments. International Journal of Police Science \& Management, 13(3), 243-254. http://dx.doi.org/10.1350/ijps.2011.13.3.228

Karasek, R. A. (1985). Job content instrument: Questionnaire and User's Guide. California: University of Southern California.

Kaufman, G. M., \& Beehr, T. A. (1981). Interactions between job stressors and social support: Some counterintuitive results. Journal of Applied Psychology, 71(3), 522-526. http://dx.doi.org/10.1037/0021-9010.71.3.522

Kawada, T., \& Otsuka, T. (2011). Relationship between job stress, occupational position, and job satisfaction using a brief job stress questionnaire (BJSQ). Work, 40(4), 393-399.

Kim, S. Y., Gu, J. T., \& Yoon, K. C. (2002). Street level police officers job stress: The degree and determination of job stress. Korean Journal of Public Administration, 40(1), 123-147.

Korunka, C., Scharitzer, D., Carayon, P., \& Sacrifort, F. (2003). Employee strain and job satisfaction related to an implementation of quality in a public service organization: A horizontal study. Work and Stress, 17(1), 52-72. http://dx.doi.org/10.1080/0267837031000109526

LaRocco, E. A. \& Jones, A. P. (1978). The coworker and leader support as moderators of stress-strain relationships in work situations. Journal of Applied Psychology, 63(5), 629-634. http://dx.doi.org/10.1037/0021-9010.63.5.629

Locke, E. A. (1976). The nature and causes of job satisfaction. In M. D. Dunnette (Ed.), Handbook of industrial and organizational psychology. Chicago, IL: Rand McNally

Maanen, J. (1975, June). Police socialization: A longitudinal examination of job attitudes in an urban police department. Administrative Science Quarterly, 20(2), 207-228. http://dx.doi.org/10.2307/2391695

Mahendran, M., \& Devanesan, P. (2013, September). Job stress and job satisfaction among employees of insurance companies. Golden Research Thoughts, 3(3), 1-5.

Mansoor, M., Fida, S., Nasir, S., \& Ahmad, Z. (2011). The impact of job stress on employee job satisfaction: A study of telecommunication sector of Pakistan. Journal of Business Studies Quarterly, 2(3), 50-56.

Marczyk, G., DeMatteo, D., \& Festinger, D. (2005). Essentials of research design and methodology. Hoboken, NJ: John Wiley \& Sons.

Menard, K. S., Arter, M. L. (2013, February). Police officer alcohol use and trauma symptoms: Association with critical incidents, coping, and social stressors. International Journal of Stress Management, 20(1), 37-56. http://dx.doi.org/10.1037/a0031434

Miller, L. (2006). Practical Police Psychology. Illinois: Charles Thomas.

Mitchel, J., Kotrba, L. M., Mitchelson, J. K., Clark, M. A., \& Baites, B. B. (2011, July). Antecedents of work-family conflict: A meta-analytic review. Journal of Organizational Behavior, 32(5), 689-725. http://dx.doi.org/10.1002/job.695 
Nele, D. C., \& Hans, D. W. (2006). Autonomy and workload among temporary workers: Their effects on job satisfaction, organizational commitment, life satisfaction, and self-related performance. International Journal of Stress Management, 13(4), 441-459. http://dx.doi.org/10.1037/1072-5245.13.4.441

Noblet, A., Rodwell, J., \& Allisey, A. (2009, February). Job stress in the law enforcement center: Comparing the linear, non-linear, and interaction effects of working conditions. Stress \& Health: Journal of the International Society for the Investigation of Stress, 25(1), 111-120. http://dx.doi.org/10.1002/smi.1227

Omlayo, B. (2012, January). Effect of gender and status on job stress among police officers in Ekti state of Nigeria. Bangladesh e-Journal of Sociology, 9(1), 38-42.

Osabutey, P. O. (2009, July). Ghana must set standard for policing in Africa. Ghanaian Chronicle. Retrieved from http//www.modernghana.com

Pagon, M., Spensor, P. E., Cooper, C. L., \& Lonikar, B. (2011, Autumn). Managers in suits and managers in uniforms: Sources and outcomes of occupational stress. International Journal of Police Science and Management, 13(3), 211-222. http://dx.doi.org/10.1350/ijps.2011.13.3.245

Rees, B., \& Smith, J. (2008, Autumn). Breaking the silence: The traumatic circle of policing. International Journal of Police Service, 10(3), 267-279.

Robbins, P. S., \& Judge, A. T. (2007). Organizational Behavior (12th ed.). New Jersey: Pearson Publishers.

Sanderam, S., \& Kumaran, M. J. (2012). A study on frequency of occupational stress among Grade 1 police constables. International Journal of Business Management and Economic Research, 3(4), 690-597.

Schult, D. P., \& Schultz, S. E. (2006). Psychology and work today (9th ed.). Upper Saddle River, NJ: Pearson Education Inc.

Sekaran, U. (1992). Research Methods for Business. New York, NY: John Wiley \& Sons.

Selokar, D., Nimbarte, S., Ahana, S., Gaidhane, A., \& Wagh, V. (2011, March). Occupational stress among police personnel of Wardha city, India. Austraian Medical Journal, 4(3), 114-517. http://dx.doi.org/10.4066/AMJ.2011.562

Sheffield, D., Dobbie, D., \& Carroll, D. (1994). Stress, social support and psychological well- being and mental health measures. Journal of Occupational and Organizational psychology, 65, 33-49.

Sijaric-Voloder, S., \& Sibila, C. D. (2008, December). Application of cognitive behavior the rapeutic techniques for prevention of psychological disorders in police officers. Health Medicine, 2(4), 288-292.

Spector, P. E. (1997). The role of frustration in anti-social behavior at work. In R. A. Giacalone \& J. Greenberg (Eds.), Anti-social behavior in workplace (pp. 1-17). Thousand Oaks, CA: Sage Publishers.

Storch, J. E., \& Panzerella, R. (1996). Police stress: State-trait anxiety in relation to occupational and personal stressors. Journal of Criminal Justice, 24(2), 99-107. http://dx.doi.org/10.1016/0047-2352(95)00058-5

Sundaram, M. S., \& Kumaran, M. J. (2012). Occupational stress and coping strategies among Grade 1 Police constables. International Journal of Business Management \& Economic Research, 3(4), 579-589.

Swanson, C. R., \& Terito, L. (1983). Police administration, structure, processes and behavior. New York: McMillan Publishers.

Tankebe, T. (2008). Colonialization, legitimation, and policing in Ghana. International Journal of Law, Crime, and Justice, 36, 67-84. http://dx.doi.org/10.1016/j.ijlcj.2007.12.003

Ussahawanitchakit, P. (2008). Building job satisfaction of Certified Public Accountants (CPAs) in Thailand: Effects of role stress through role conflict, role ambiguity, and role overload. Journal of Academy of Business \& Economics, 8(2), 12-22.

Vogt, P. W. (2007). Quantitative research methods for professionals. Boston, MA: Allyn and Bacon.

Wilkins, K., \& Beaudet, M. P. (1998). Work stress and health. Health Reports, 10(3), 47-62.

Yu-Chi, W. (2011). Job stress and job performance among employees in the Taiwanese finance sector: The role of emotional intelligence. Social Behavior \& Personality: An International Journal, 39(1), 21-31. http://dx.doi.org/10.2224/sbp.2011.39.1.21

Yu-Fen, C. (2009). Job stress and performance: A study of police officers in Central Taiwan. Social Behavior \& Personality: An International Journal, 37(10), 1341-1356. 


\section{Copyrights}

Copyright for this article is retained by the author(s), with first publication rights granted to the journal.

This is an open-access article distributed under the terms and conditions of the Creative Commons Attribution license (http://creativecommons.org/licenses/by/3.0/). 